\title{
Novel Yeast Protein Kinase (YPK1 Gene Product) Is a 40-Kilodalton Phosphotyrosyl Protein Associated with Protein-Tyrosine Kinase Activity
}

\author{
DAVID DAILEY, ${ }^{1}$ GARY L. SCHIEVEN,${ }^{1,2}$ MOON YOUNG LIM,${ }^{1}$ HANS MARQUARDT,${ }^{2}$ THOMAS GILMORE, ${ }^{1 \dagger}$ \\ JEREMY THORNER, ${ }^{1 *}$ AND G. STEVEN MARTIN ${ }^{1 *}$ \\ Division of Biochemistry and Molecular Biology, Department of Molecular and Cell Biology, University of California, \\ Berkeley, California $94720,{ }^{1}$ and Oncogen, Bristol-Myers Squibb Pharmaceutical Research Institute,
} Seattle, Washington $98121^{2}$

Received 4 June 1990/Accepted 23 August 1990

\begin{abstract}
Extracts of bakers' yeast (Saccharomyces cerevisiae) contain protein-tyrosine kinase activity that can be detected with a synthetic Glu-Tyr copolymer as substrate (G. Schieven, J. Thorner, and G. S. Martin, Science 231:390-393, 1986). By using this assay in conjunction with ion-exchange and affinity chromatography, a soluble tyrosine kinase activity was purified over $\mathbf{8 , 0 0 0}$-fold from yeast extracts. The purified activity did not utilize typical substrates for mammalian protein-tyrosine kinases (enolase, casein, and histones). The level of tyrosine kinase activity at all steps of each preparation correlated with the content of a 40-kDa protein (p40). Upon incubation of the most highly purified fractions with Mn-ATP or Mg-ATP, p40 was the only protein phosphorylated on tyrosine. Immunoblotting of purified p40 or total yeast extracts with antiphosphotyrosine antibodies and phosphoamino acid analysis of ${ }^{32} \mathrm{P}$-labeled yeast proteins fractionated by sodium dodecyl sulfate-polyacrylamide gel electrophoresis indicated that the $40-\mathrm{kDa}$ protein is normally phosphorylated at tyrosine in vivo. ${ }^{32} \mathrm{P}$-labeled $\mathbf{p 4 0}$ immunoprecipitated from extracts of metabolically labeled cells by affinitypurified anti-p40 antibodies contained both phosphoserine and phosphotyrosine. The gene encoding p40 (YPK1) was cloned from a yeast genomic library by using oligonucleotide probes designed on the basis of the sequence of purified peptides. As deduced from the nucleotide sequence of YPK1, p40 is homologous to known protein kinases, with features that resemble known protein-serine kinases more than known protein-tyrosine kinases. Thus, $\mathbf{p 0}$ is a protein kinase which is phosphorylated in vivo and in vitro at both tyrosine and serine residues; it may be a novel type of autophosphorylating tyrosine kinase, a bifunctional (serine/tyrosine-specific) protein kinase, or a serine kinase that is a substrate for an associated tyrosine kinase.
\end{abstract}

Protein-tyrosine kinases are involved in growth control and malignant transformation of animal cells $(22,23)$. A large number of protein-tyrosine kinases, including a number of growth factor receptors (48), have been described in both vertebrates and invertebrates (20). The molecular mechanisms by which these enzymes affect cellular growth and induce transformation remain unclear, despite the identification of some substrates for these enzymes $(11,14,22,38)$. To further elucidate the role of protein-tyrosine kinases in normal cells, we began an examination of the proteintyrosine kinases of bakers' yeast (Saccharomyces cerevisiae). S. cerevisiae offers an attractive system for study of eucaryotic growth control because of its short generation time, its small genome size, the availability of numerous cell division cycle mutations (37), and the ease of application of molecular genetic methods (such as gene replacement) (2).

We have demonstrated previously that $S$. cerevisiae contains a soluble activity capable of phosphorylating both exogenous substrates, such as poly $\left(\mathrm{Glu}^{80} \mathrm{Tyr}^{20}\right)$ copolymer, and unknown endogenous yeast proteins on tyrosine (43). The presence of a kinase activity in $S$. cerevisiae plasma membranes capable of phosphorylating casein on tyrosine has also been reported (8). More recently, it has been shown that in the fission yeast Schizosaccharomyces pombe, the

\footnotetext{
* Corresponding authors.

† Present address: Biology Department, Boston University, Boston, MA 02215.
}

product of the $c d c 2^{+}$gene, p34 $4^{c d c 2}$, is phosphorylated transiently at tyrosine (19).

In light of these observations, we have further characterized the tyrosine kinase activity that we detected in yeast cells. We have reproducibly resolved from yeast extracts four chromatographically distinct kinase activities capable of phosphorylating poly $\left(\mathrm{Glu}^{80} \mathrm{Tyr}^{20}\right)$ on tyrosine. Here we describe the purification and characterization of one of these enzymes. The purified protein-tyrosine kinase activity is associated with a $40-\mathrm{kDa}$ yeast protein which is phosphorylated on tyrosine both in vivo and in vitro. The gene encoding this protein was cloned, and its sequence revealed that the $40-\mathrm{kDa}$ polypeptide is a protein kinase that most closely resembles previously described protein-serine kinases. Tyrosine phosphorylation of p40 may result either from autophosphorylation or from phosphorylation by an associated protein-tyrosine kinase.

\section{MATERIALS AND METHODS}

Growth of yeast cells. The haploid yeast strain AB103 (MAT $\alpha$ leu2-3 ura3-52 pep4-3 his4-580 CIR ${ }^{+}$) (18) was used for this work. The pep4-3 mutation in the structural gene for protease $A(1)$ prevents activation of the zymogen forms of protease B and carboxypeptidase $Y(25)$, resulting in a 90 to $95 \%$ reduction in all three vacuolar proteases (33). Before use, inocula were tested for the $\mathrm{Pep}^{-}$phenotype by screening colonies with an activity stain (24) that detects active carboxypeptidase Y. Yeast cells were grown to mid-exponential phase in YPD medium (46) (1\% yeast extract, $2 \%$ 
peptone, $2 \%$ glucose) at $30^{\circ} \mathrm{C}$ in a 200 -liter fermentor with vigorous aeration and were collected by using an air-driven Sharples Super centrifuge. Cells were stored at $-70^{\circ} \mathrm{C}$. For purification of large quantities of material, fresh wet blocks of commercial Red Star bakers' yeast (Universal Foods, Oakland, Calif.) were used as starting material.

Preparation of yeast cell extracts. Yeast cells $(100 \mathrm{~g})$ were thawed, washed twice by suspension in ice-cold lysis buffer

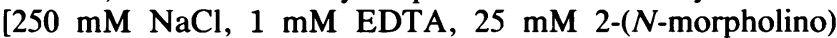
ethanesulfonic acid (MES) ( $\mathrm{pH}$ 6.5)], and collected by centrifugation at $5,000 \times g$ for $10 \mathrm{~min}$. The washed cells were then suspended in ice-cold lysis buffer containing protease inhibitors ( $1 \mathrm{mM}$ phenylmethylsulfonyl fluoride [PMSF], 3 $\mu \mathrm{g}$ of pepstatin A per $\mathrm{ml}, 2 \mathrm{mM}$ benzamidine hydrochloride) to a final volume of $100 \mathrm{ml} / 30 \mathrm{~g}$ of cells. When commercially grown yeast cells were used, the lysis buffer was supplemented with $1 \mathrm{mM}$ PMSF, $0.01 \mathrm{mM}$ benzamidine hydrochloride, $1 \mu \mathrm{g}$ of phenanthroline per $\mathrm{ml}$, and $0.5 \mu \mathrm{g}$ each of antipain, leupeptin, pepstatin A, chymostatin, and aprotinin per $\mathrm{ml}$. Cells were lysed by passage five times through a Manton-Gaulin homogenizer at 8,000 to $9,000 \mathrm{lb} / \mathrm{in}^{2}$. The lysate was subjected to centrifugation at $5,000 \times g$ for $20 \mathrm{~min}$ to remove unbroken cells and debris, and the supernatant solution was collected as the crude extract.

Enzyme assays. Assays of tyrosine kinase activity were performed by using poly $\left(\mathrm{Glu}^{80} \mathrm{Tyr}^{20}\right)$ as the substrate as described previously (43), with the following modifications. The reaction of poly $\left(\mathrm{Glu}^{80} \mathrm{Tyr}^{20}\right)$ with $\left[\gamma^{-32} \mathrm{P}\right]$ ATP was terminated by the addition of 2.5 volumes of electrophoresis buffer (9.4 M urea, 62.5 mM Tris hydrochloride [pH 6.8], $0.0002 \%$ bromophenol blue) containing $30 \mathrm{mM}$ ATP. Samples were analyzed by gel electrophoresis without prior precipitation with trichloroacteic acid (TCA). Electrophoresis was carried out as previously described (43) except that Nonidet P-40 detergent was omitted from the electrophoresis buffer. One unit of activity was defined as $1 \mathrm{fmol}$ of phosphate transferred to tyrosine under the assay conditions (10-min incubation). Protein concentrations were determined by the dye-binding method of Bradford (3).

PAGE. Procedures for sodium dodecyl sulfate (SDS)polyacrylamide gel electrophoresis (PAGE) were as described previously (30). Silver staining of polyacrylamide gels was carried out as described previously (35). Unstained and prestained molecular weight markers were obtained from Sigma; under the conditions used here, the electrophoretic mobility of prestained porcine heart fumarase corresponded to an apparent $M_{\mathrm{r}}$ of 52,000 , and that of prestained chicken muscle pyruvate kinase corresponded to an apparent $M_{\mathrm{r}}$ of 70,000 .

Ammonium sulfate fractionation. Crude extracts of AB103 cells were subjected to centrifugation at $165,000 \times g$ for $5 \mathrm{~h}$ in a Beckman $45 \mathrm{Ti}$ rotor. For larger-scale preparations using commercial yeast cells, crude extracts were clarified (under the same centrifugation conditions) for only 30 min because of the large volumes of extract to be processed. The supernatant solution was collected as the soluble fraction, and the volume was adjusted with lysis buffer to a protein concentration of $5 \mathrm{mg} / \mathrm{ml}$. Ammonium sulfate (ultrapure; Schwarz/ Mann) was added slowly to $45 \%$ saturation with stirring on ice, and the solution was stirred for an additional $20 \mathrm{~min}$. Precipitated proteins were collected by centrifugation at $5,000 \times g$ for $30 \mathrm{~min}$ and dissolved in buffer A ( $1 \mathrm{mM}$ EDTA, $20 \mathrm{mM}$ Tris hydrochloride [pH 8.0]) containing $1 \mathrm{mM}$ PMSF, $3 \mu \mathrm{g}$ of pepstatin A per $\mathrm{ml}$, and $2 \mathrm{mM}$ benzamidine hydrochloride. This solution was clarified by centrifugation at $15,000 \times g$ for $30 \mathrm{~min}$.
Chromatographic fractionation. Gradients for low-pressure columns and high-pressure (fast protein liquid chromatography [FPLC]) columns were generated by a Beckman $114 \mathrm{M}$ high-performance liquid chromatography system. FPLC columns were loaded by using either conventional sample loops or a 50-ml Superloop (Pharmacia), depending on sample volume. Unless otherwise stated, all purification procedures were performed at $4^{\circ} \mathrm{C}$. For storage between purification steps, enzyme solutions were made $50 \%$ in glycerol and maintained at $-20^{\circ} \mathrm{C}$.

The clarified ammonium sulfate fraction was made $25 \%$ in glycerol and further diluted with buffer A plus $25 \%$ glycerol to a conductivity of less than $7.5 \mathrm{mS}$ before loading onto a bed of Q-Sepharose (Pharmacia) in a column $(2.5$ by $20 \mathrm{~cm})$ equilibrated with buffer A plus $25 \%$ glycerol. For largerscale preparations, the ammonium sulfate pellet was resuspended in buffer $\mathrm{A}$ and dialyzed extensively against buffer $\mathrm{A}$ before glycerol addition and column loading.

Proteins that passed through the Q-Sepharose column were collected and pooled. Proteins that bound to the column were eluted with a linear gradient of 0 to $500 \mathrm{mM}$ $\mathrm{NaCl}$ in equilibration buffer in a total volume of $500 \mathrm{ml}$. The $\mathrm{pH}$ of the pooled fractions containing the proteins that passed through the column was adjusted with 1 M MES to $\mathrm{pH}$ 6.5, and the solution was loaded onto a bed of S-Sepharose (Pharmacia) in a column $(1.5$ by $12.5 \mathrm{~cm})$ equilibrated with buffer B (1 mM EDTA, 25\% glycerol, $50 \mathrm{mM}$ MES [pH 6.5]). After washing of the column with buffer B until the $A_{280}$ of the eluant returned to base line, the bound proteins were eluted with a gradient of 0 to $430 \mathrm{mM} \mathrm{NaCl}$ in buffer $B$ in a total volume of $360 \mathrm{ml}$. Fractions of $10 \mathrm{ml}$ were collected for enzyme assay.

A bed of orange A-agarose (Amicon) in a column ( 1.5 by 6 $\mathrm{cm}$ ) was washed overnight with $8 \mathrm{M}$ urea to remove free dye contaminants and then equilibrated with buffer C $(10 \mathrm{mM}$ $\mathrm{MnCl}_{2}, 0.1 \%$ Triton X-100 [Sigma], $20 \mathrm{mM}$ bis-Tris propane [pH 6.75]). Pooled active fractions from the S-Sepharose eluate were diluted fourfold in buffer $\mathrm{C}$ before loading onto the orange A-agarose column. The column was then washed with an additional $15 \mathrm{ml}$ of buffer $\mathrm{C}$, followed by $30 \mathrm{ml}$ of 5 $\mathrm{mM}$ EDTA-0.1\% Triton X-100-20 mM bis-Tris propane ( $\mathrm{pH}$ 7.5). Proteins bound to the column were eluted with a linear gradient of 0 to $1.5 \mathrm{M} \mathrm{NaCl}$ in $1 \mathrm{mM}$ EDTA-0.1\% Triton $\mathrm{X}-100-20 \mathrm{mM}$ bis-Tris propane) ( $\mathrm{pH} 7.5)$ in a total volume of $80 \mathrm{ml}$.

Pooled active fractions from the orange A-agarose column were diluted 10 -fold in buffer D ( $1 \mathrm{mM}$ EDTA, $0.1 \%$ Triton $\mathrm{X}-100,50 \mathrm{mM}$ MES [pH 6.5]) and loaded onto a Mono S column (HR5/5; Pharmacia) equilibrated with buffer D. After the column was washed with $5 \mathrm{ml}$ of buffer $\mathrm{D}$, bound proteins were eluted with a linear gradient of 0 to $1 \mathrm{M} \mathrm{NaCl}$ in buffer $D$ in a total volume of $46 \mathrm{ml}$. The active fractions were pooled, adjusted to $50 \%$ glycerol, and stored at $-20^{\circ} \mathrm{C}$.

Phosphoamino acid analysis of radiolabeled proteins. Slices of dried gels containing labeled proteins were rehydrated in $800 \mu \mathrm{l}$ of $6 \mathrm{~N} \mathrm{HCl}$ and incubated at $110^{\circ} \mathrm{C}$ for $80 \mathrm{~min}$. The hydrolysates were removed from the insoluble polyacrylamide gel slice, lyophilized, and redissolved in water. In some experiments, the redissolved hydrolysate was subjected to anion-exchange chromatography on Dowex AG1-X8 $\left(\mathrm{Cl}^{-}\right.$form; Bio-Rad $)$to separate the phosphoamino acids from the contaminants that occasionally interfere with subsequent thin-layer separations (12). When large gel slices were to be analyzed, the protein was eluted with $0.5 \mathrm{M}$ $\mathrm{NaHCO}_{3}-0.1 \%$ SDS-5\% $\beta$-mercaptoethanol-carrier protein (bovine immunoglobulin; $75 \mu \mathrm{g}$ ), and the protein was pre- 
cipitated at $0^{\circ} \mathrm{C}$ with $20 \%$ TCA; the precipitated protein was isolated by centrifugation, washed with ethanol, and hydrolyzed as described above. Redissolved hydrolysates or the Dowex eluates were subjected to two-dimensional electrophoresis on cellulose thin-layer plates and examined by autoradiography as described previously (12). A modified procedure was used when multiple samples containing low levels of phosphotyrosine were to be analyzed (see legend to Fig. 10). Hydrolysates were subjected to electrophoresis for $5 \mathrm{~h}$ at $\mathrm{pH}$ 1.9. Areas of the plate containing phosphothreonine and phosphotyrosine (identified by autoradiography of dried plates) were scraped off, and the phosphoamino acids were eluted. The samples were then subjected to twodimensional electrophoresis, with electrophoresis at $\mathrm{pH} 1.9$ for only $1 \mathrm{~h}$ in the first dimension and at $\mathrm{pH} 3.5$ for $2 \mathrm{~h}$ in the second.

Preparation of antiphosphotyrosine antibodies. Antiphosphotyrosine antibodies were initially provided by Mark Kamps (Salk Institute, La Jolla, Calif.). Subsequently, we prepared antiphosphotyrosine antibodies by minor modifications of methods previously described (27), using as the immunogen a copolymer of phosphotyrosine, glycine, and alanine coupled to keyhole limpet hemocyanin. The antiphosphotyrosine antibodies were purified by affinity chromatography on phosphotyramine (synthesized as previously described [41]) coupled to Affigel 10 (Bio-Rad).

Preparation and affinity purification of anti-p40 antiserum. Proteins in the Mono $\mathrm{S}$ fractions were precipitated by addition of sodium deoxycholate and TCA to final concentrations of $0.4 \mathrm{mg} / \mathrm{ml}$ and $10 \%$, respectively. The pellets were washed once with $10 \%$ TCA and twice with acetone, boiled in SDS sample buffer, and subjected to preparative SDSPAGE. The gel was stained briefly in Coomassie blue $\mathbf{( 0 . 0 5 \%}$ in $\mathrm{H}_{2} \mathrm{O}$ ) and rinsed for $10 \mathrm{~min}$ in water. The single wellisolated band containing p40 was excised, crushed, and homogenized with complete (first two injections) or incomplete (third injection) Freund adjuvant. A rabbit was immunized subcutaneously (10 to $20 \mu \mathrm{g}$ of protein per injection) three times at 21-day intervals, and serum was collected weekly beginning 14 days after the third injection.

For affinity purification of anti-p40 antibody, a p40 antigen column was prepared as follows. Mono $\mathrm{S}$ fractions were subjected to SDS-PAGE, after concentration by TCA precipitation, as described above. The p40-containing gel band was crushed, boiled in $0.1 \%$ SDS-50 mM ammonium bicarbonate- $550 \mathrm{mM} \beta$-mercaptoethanol for $5 \mathrm{~min}$, and agitated at $37^{\circ} \mathrm{C}$ overnight. The gel fragments were removed by centrifugation, and the p40 in the eluate was precipitated with $10 \%$ TCA, washed once with $10 \%$ TCA and twice with acetone, and suspended in coupling buffer $(0.5 \mathrm{M} \mathrm{NaCl}, 0.1 \mathrm{M}$ $\mathrm{NaHCO}_{3}$ [pH 8.3]) plus $0.1 \%$ SDS. p40 $(200 \mu \mathrm{g})$ recovered in this manner was coupled to $1 \mathrm{ml}$ of $\mathrm{CNBr}$-activated Sepharose 4B (Pharmacia) as instructed by the manufacturer. After coupling, the column was washed with $5 \mathrm{ml}$ of $100 \mathrm{mM}$ Tris chloride ( $\mathrm{pH} \mathrm{8.0)}$ to block any residual active groups on the beads. To remove uncoupled antigen, the column was washed first with $8 \mathrm{ml}$ of $0.5 \mathrm{M} \mathrm{NaCl}-100 \mathrm{mM}$ sodium acetate (pH 4.0) and then with $8 \mathrm{ml}$ of $100 \mathrm{mM} 0.5 \mathrm{M}$ $\mathrm{NaCl}-\mathrm{Tris}$ chloride ( $\mathrm{pH} 8.0$ ); these wash steps were repeated twice. To ensure complete antigen removal, the column was then washed sequentially with $15 \mathrm{ml}$ of $6 \mathrm{M}$ guanidine

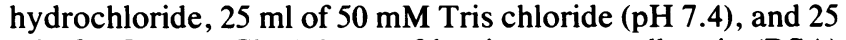
$\mathrm{ml}$ of $4.5 \mathrm{M} \mathrm{MgCl}_{2}-1.0 \mathrm{mg}$ of bovine serum albumin (BSA)

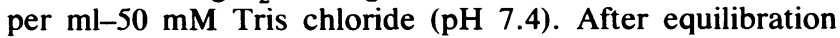

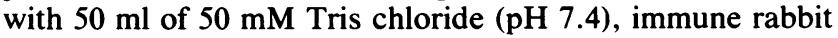
serum $(20 \mathrm{ml})$ was passed slowly over the column twice. The column was then washed sequentially with $20 \mathrm{ml}$ of $50 \mathrm{mM}$ Tris chloride ( $\mathrm{pH} 7.4), 40 \mathrm{ml}$ of $1.0 \mathrm{M}$ guanidine hydrochloride, and $20 \mathrm{ml}$ of $50 \mathrm{mM}$ Tris chloride ( $\mathrm{pH} \mathrm{7.4).} \mathrm{Bound}$ antibodies were eluted from the column first with $10 \mathrm{ml}$ of 4.5

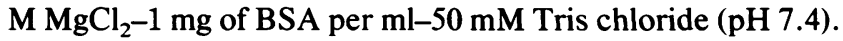
After reequilibration with $50 \mathrm{mM}$ Tris chloride ( $\mathrm{pH} 7.4$ ), remaining antibodies were eluted with $10 \mathrm{ml}$ of $0.1 \mathrm{M}$ glycine $(\mathrm{pH} 2.5)$. The eluted fractions were dialyzed extensively against $30 \%$ glycerol $-0.02 \%$ sodium azide in phosphatebuffered saline (150 mM NaCl, $3 \mathrm{mM} \mathrm{KCl}, 7 \mathrm{mM} \mathrm{Na}_{2} \mathrm{HPO}_{4}$, $1.6 \mathrm{mM} \mathrm{KH}_{2} \mathrm{PO}_{4}$ ) and stored at $-20^{\circ} \mathrm{C}$.

Radiolabeling of yeast cells and immunoprecipitation of radiolabeled $\mathbf{p 4 0}$. For labeling with ${ }^{32} \mathrm{P}_{\mathrm{i}}$, low-phosphate medium (LPSM) was used (40). A saturated overnight culture of AB103 in LPSM was diluted 10-fold into fresh LPSM and cultured for $2 \mathrm{~h}$ at $30^{\circ} \mathrm{C}$. Radiolabel $\left(10 \mathrm{mCi}\right.$ of $\left.{ }^{32} \mathrm{P}_{\mathrm{i}}\right)$ in $1 \mathrm{ml}$ of fresh LPSM was then added to $1 \mathrm{ml}$ of the growing culture, and growth continued for $4 \mathrm{~h}$. The cells were then chilled, harvested by centrifugation, washed twice with ice-cold phosphate-buffered saline, and lysed in 1\% SDS by vortexing with glass beads followed immediately by boiling for $3 \mathrm{~min}$. The boiled lysate was diluted with $1 \mathrm{ml}$ of immunoprecipitation buffer (1\% [wt/vol] Triton X-100, $0.5 \%$ [wt/vol] sodium deoxycholate, $0.1 \%$ [wt/vol] SDS in phosphate-buffered saline), and boiled again for $1 \mathrm{~min}$, and immunoprecipitation was performed as described previously (26). Briefly, $250 \mu \mathrm{l}$ of lysate was precleared with $25 \mu \mathrm{l}$ of a $10 \%$ suspension of fixed Staphylococcus aureus (IgSorb; The Enzyme Center, Boston, Mass.), $2.5 \mu l$ of preimmune rabbit serum, and a second sample of IgSorb. The lysate was then incubated with either $10 \mu \mathrm{l}$ of anti-p40 or $2.5 \mu \mathrm{l}$ of preimmune rabbit serum, and the antigen-antibody complexes were collected by addition of $25 \mu$ l of IgSorb which had been preblocked with unlabeled lysate. The IgSorb pellets were then washed as described previously (26) and boiled in SDS sample buffer. Labeled proteins in the supernatant solution were analyzed by SDS-PAGE and autoradiography.

Immunoblotting with anti-p40 or antiphosphotyrosine antibodies. Immunoblotting was performed as described previously (6), with the following modifications. After SDSPAGE, proteins were electrophoretically transferred to polyvinylidene difluoride (PVDF) membranes (Millipore). Transfer was at $50 \mathrm{~V}$ for $90 \mathrm{~min}$ at $4^{\circ} \mathrm{C}$ in buffer containing 25 $\mathrm{mM}$ Tris and $192 \mathrm{mM}$ glycine. For antiphosphotyrosine immunoblotting, blots were blocked with 5\% BSA in Trissaline (20 mM Tris hydrochloride [pH 7.2], $150 \mathrm{mM} \mathrm{NaCl}$ ) for $1 \mathrm{~h}$. For anti-p40 immunoblotting, blots were blocked with $5 \%$ nonfat dry milk in Tris-saline for $1 \mathrm{~h}$. Blocked blots were incubated with either antiphosphotyrosine antibody ( 2 $\mu \mathrm{g} / \mathrm{ml})$ or anti-p40 antibody (1:200 dilution of the pooled $\mathrm{MgCl}_{2}$ and glycine eluates) for $1 \mathrm{~h}$, washed twice for $20 \mathrm{~min}$ with Tris-saline containing $0.05 \%$ Nonidet $\mathrm{P}-40$, and then incubated with either ${ }^{125} \mathrm{I}$-protein $\mathrm{A}(10 \mu \mathrm{Ci} / \mathrm{ml}$; ICN $)$ or alkaline-phosphatase-conjugated goat anti-rabbit secondary antibody (1:2,500 in Tris-saline containing 5\% BSA; BioRad) for $1 \mathrm{~h}$. Blots were washed twice with the same wash buffer for $20 \mathrm{~min}$ each. Blots probed with ${ }^{125} \mathrm{I}$-protein A were dried and subjected to autoradiography. Blots probed with secondary antibody were stained with the alkaline phosphatase substrates, $p$-nitroblue tetrazolium chloride $(0.3$ $\mathrm{mg} / \mathrm{ml})$, and 5-bromo-4-chloro-3-indolyl phosphate $(0.15 \mathrm{mg} /$ $\mathrm{ml}$ ) in $50 \mathrm{mM} \mathrm{NaHCO} 3(\mathrm{pH} 9.8)-100 \mathrm{mM} \mathrm{NaCl}-5 \mathrm{mM}$ $\mathrm{MgCl}_{2}$.

Digestion with protease V8. After SDS-PAGE, proteins were identified by brief staining with Coomassie brilliant 
blue. Gel slices containing protein were excised and subjected to partial proteolysis by $S$. aureus V8 protease as described previously (10). Peptides resolved by SDS-PAGE were transferred to PVDF membranes and detected by immunoblotting or by staining with colloidal gold (AuroDye forte; Amersham, UK) as instructed by the manufacturer.

Sequencing of $\mathrm{p40}$ peptides and isolation of the $\mathrm{p} 40$ gene. To obtain peptide sequence, Mono S-purified p40 (10 $\mu$; Mono $\mathrm{S}$, peak B) was subjected to preparative SDS-PAGE. The Coomassie blue-stained $\mathrm{p} 40$ protein was recovered from the gel by electroelution (21). SDS was removed from the lyophilized protein sample by washing with $90 \%$ ethanol at $-20^{\circ} \mathrm{C}, 90 \%$ acetone at $-20^{\circ} \mathrm{C}$, and acetone-triethylamineacetic acid $(90: 7: 3)$ for $30 \mathrm{~min}$ at $0^{\circ} \mathrm{C}$. The protein was reduced and pyridylethylated, desalted, and treated with endoproteinase Lys- $C$, and peptides were separated by reverse-phase high-performance liquid chromatography (32). The resulting peptides were sequenced in a pulsed-liquid protein sequencer (model 475A; Applied Biosystems, Inc.) with an on-line model 120A PTH analyzer.

To isolate the p40 gene, three unique (nondegenerate) oligonucleotide probes were designed by reverse translation of peptides 4,8 , and 10 , using the codons most commonly found for $S$. cerevisiae proteins (13). These probes were then used to screen a library of yeast genomic DNA in the vector YEp24 (7). One clone that hybridized well to all three oligonucleotides was isolated. A 3.9-kb ClaI-Pst I fragment of the insert in this clone was then subcloned into pBluescript $\mathrm{SK}^{+}$and $\mathrm{SK}^{-}$(Stratagene), and nested deletions were generated by using exonuclease III and mung bean nuclease (Stratagene). The resulting clones were sequenced by the method of Sanger et al. (42) with modified T7 DNA polymerase (Sequenase 2.0; United States Biochemical). The complete sequence of both strands was determined.

Nucleotide sequence accession number. The GenBank ac- cession number for the sequence reported in this paper is M55984.

\section{RESULTS}

Fractionation of yeast protein-tyrosine kinase activities. To purify yeast tyrosine kinases, extracts were initially prepared from a protease-deficient strain, AB103. Exponentialphase cells were used, although no significant difference was observed in total tyrosine kinase activity between exponentially growing cells and cells grown to stationary phase. For the purification of larger quantities of material, commercially grown yeast cells were lysed in the presence of an extensive array of protease inhibitors, and results similar to those observed with $\mathrm{AB} 103$ were obtained.

Despite precautions against proteolysis, the half-life of the tyrosine kinase activity in crude extracts at $4^{\circ} \mathrm{C}$ was found to be less than $5 \mathrm{~h}$. The half-life could be extended significantly by storing the fraction in $50 \%$ glycerol at $-20^{\circ} \mathrm{C}$. Therefore, glycerol was used throughout the purification to stabilize enzyme activity. Upon separation of the clarified crude extract into a soluble and a particulate fraction, $70 \%$ of the total tyrosine kinase activity was found in the soluble fraction. Because the majority of the activity was soluble, this fraction was subjected to further fractionation. Ammonium sulfate precipitation was used to concentrate and purify the activity present in the soluble fraction. At a protein concentration of $5 \mathrm{mg} / \mathrm{ml}$, addition of ammonium sulfate to $45 \%$ saturation precipitated virtually all of the kinase activity and provided substantial purification (Table 1). At this stage, the kinase activity could be stored in $50 \%$ glycerol at $-20^{\circ} \mathrm{C}$ for 2 weeks without loss of activity.

Anion-exchange chromatography on a Mono Q FPLC column resulted in the resolution of four species, designated Q1 to Q4 in the order of their elution (Fig. 1). The Q1 species

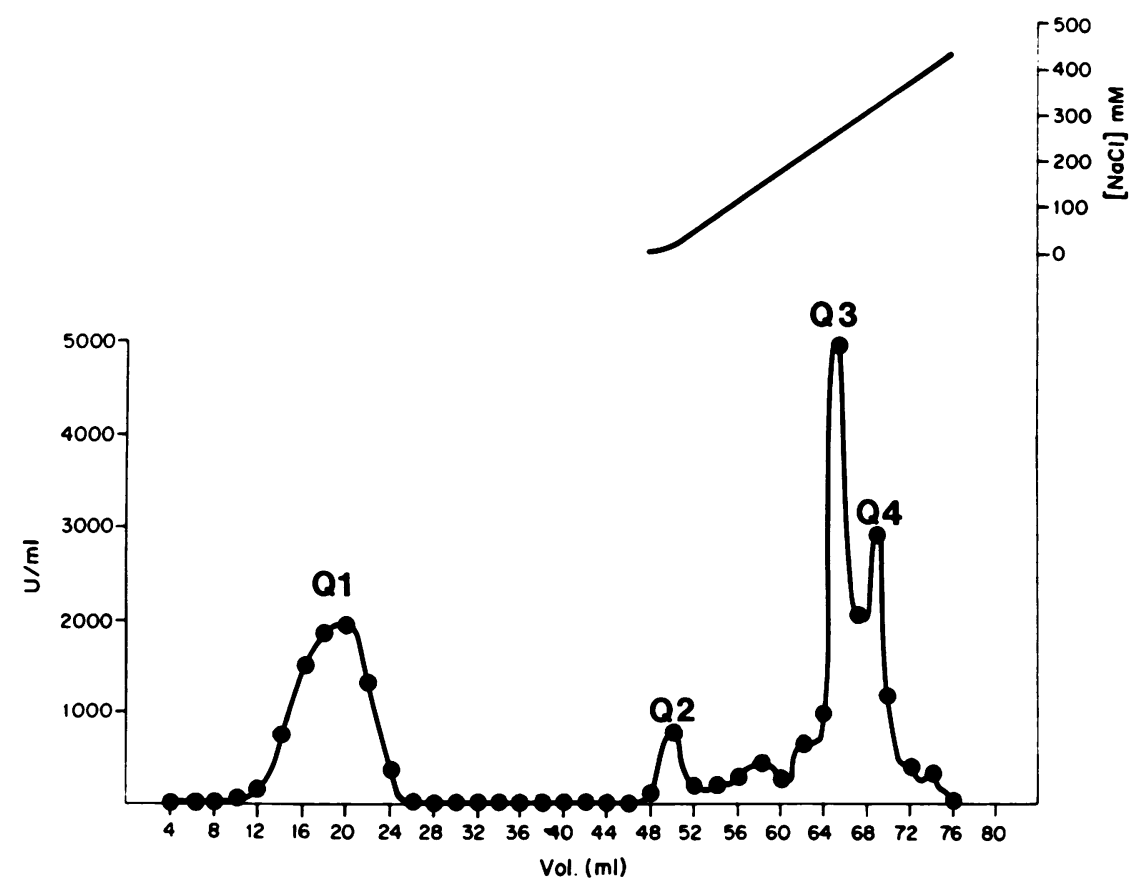

FIG. 1. Fractionation of yeast tyrosine kinase activities by Mono $Q$ chromatography. A sample of the redissolved ammonium sulfate precipitate of a preparation from $\mathrm{AB} 103$ cells $(50,0000 \mathrm{U}$ total) was applied to a Mono Q column equilibrated with buffer A (see Materials and Methods). After washing of the column with $25 \mathrm{ml}$ of buffer A, proteins were eluted with a linear gradient ( $\longrightarrow$ ) of $\mathrm{NaCl}$ in buffer A. Fractions of $2 \mathrm{ml}$ were collected, and enzyme activity was assayed in every fraction (๑). Active species were designated Q1 to Q4, in order of elution. 
TABLE 1. Purification of tyrosine kinases from yeast cells ${ }^{a}$

\begin{tabular}{lcrrrr}
\hline \multicolumn{1}{c}{ Sample } & $\begin{array}{c}\text { Protein } \\
(\mathrm{mg})\end{array}$ & \multicolumn{1}{c}{$\begin{array}{c}\text { Activity } \\
(\mathrm{U})^{b}\end{array}$} & $\begin{array}{c}\text { Sp act } \\
(\mathrm{U} / \mathrm{mg})\end{array}$ & Purificationc $^{c}$ & $\begin{array}{c}\text { Yield } \\
(\%)\end{array}$ \\
\hline Lysate & 4,620 & 610,000 & 130 & 1.0 & 100 \\
Soluble fraction & 2,187 & 427,000 & 200 & 1.5 & 70 \\
Ammonium sulfate & 154 & 523,500 & 3,400 & 26 & 86 \\
Q-Sepharose & & & & & \\
Q1 & 24.5 & 112,600 & 4,600 & 89 & 18 \\
Q2 & 21.0 & 87,600 & 4,200 & 102 & 14 \\
Q3 & 46.0 & 85,800 & 1,900 & 47 & 14 \\
Q1 & & & & & \\
S-Sepharose & 1.37 & 36,840 & 27,000 & 521 & $33^{d}$ \\
Orange A-agarose & 0.064 & 26,740 & 420,000 & 8,094 & $25^{d}$ \\
\hline
\end{tabular}

${ }^{a}$ Preparation started with $100 \mathrm{~g}$ (wet weight) of AB103 cells.

${ }^{b}$ One unit represents $1 \mathrm{fmol}$ of phosphate transferred in a 10 -min reaction.

c Calculation of the degree of purification includes the separation of the total activity into three species.

${ }^{d}$ As a percentage of the Q1 activity from the Q-Sepharose column.

comprised $40 \%$ of the total kinase activity. The amount of the Q2 species recovered varied considerably, even between preparations from identical lots of yeast cells, and it was not extensively characterized. The Q3 and Q4 species displayed an increasing instability upon further purification, precluding detailed characterization. The chromatographic properties of these different species on further purification (data not shown) suggested that $\mathrm{Q} 1$ and $\mathrm{Q} 2$ are related and that $\mathrm{Q} 3$ and Q4 are related. Both the Q1 and Q3 species appeared to be hydrophobic, because they bound irreversibly to a variety of hydrophobic matrices.

Purification of Q1 activity. For preparative purposes, the Q1 fraction was separated from the other tyrosine kinase activities by Q-Sepharose chromatography. The Q1 fraction was then absorbed to S-Sepharose (a cation-exchange resin) at $\mathrm{pH} 6.5$ and eluted as a single peak at approximately 150 $\mathrm{mM} \mathrm{NaCl}$ with substantial purification (Table 1). This purification step resulted in a marked increase in stability, increasing the half-life to 80 days upon storage in $50 \%$ glycerol at $-20^{\circ} \mathrm{C}$.

Further purification was achieved by dye-ligand affinity chromatography on orange A-agarose (Table 1). Inclusion of Triton X-100 in the column buffers was necessary for recovery of the Q1 activity in this step. Analysis of the material from each stage of the purification by SDS-PAGE and silver staining indicated that only a few protein species were present in the most highly purified fractions (Fig. 2). The content of only one protein, of apparent $M_{\mathrm{r}} 40,000$, correlated with the level of protein-tyrosine kinase activity upon both S-Sepharose ion-exchange chromatography and orange A affinity chromatography (Fig. 2). The same correlation of activity with the $40-\mathrm{kDa}$ protein was observed reproducibly in 10 independent preparations.

Cochromatography of activity with the $40-\mathrm{kDa}$ protein was also observed upon subsequent fractionation of the pooled orange A-agarose eluate on Mono S (Fig. 2 and 3). Both p40 and enzyme activity eluted as two peaks, designated peak $A$ and peak $B$. This was observed both in preparations from AB103 and in larger-scale preparations from commercially grown yeast cells. The larger-scale preparations gave somewhat less purification, as indicated by the presence of many other protein species detectable by silver staining after SDS-PAGE (Fig. 3). The cochromatography of p40 and enzyme activity on Mono S FPLC provided further evidence that $\mathrm{p} 40$ either is the phosphotransferase responsible for phosphorylation of the poly $\left(\mathrm{Glu}^{80} \mathrm{Tyr}^{20}\right)$ copolymer or is closely associated with it. Subsequent experiments (see

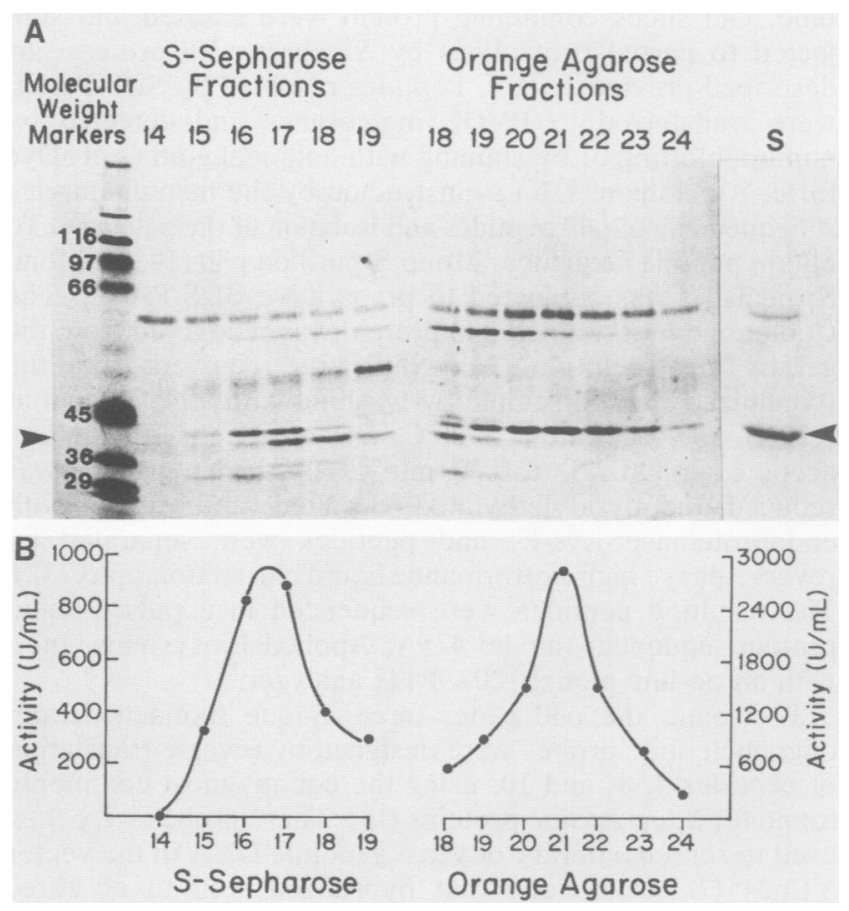

FIG. 2. Coelution of p40 with tyrosine kinase activity. (A) Protein species present in equal volumes of fractions from the last three steps of a purification from AB103 cells were analyzed by SDSPAGE and silver staining. Lanes: 14 to 19 , fractions $(15 \mathrm{ml})$ from S-Sepharose chromatography; 18 to 24 , fractions $(4 \mathrm{ml})$ from the subsequent orange A-agarose chromatography; $S$, final pooled peak of active fractions from Mono $S$ chromatography (stained with Coomassie blue). (B) Profiles of enzyme activity across the column fractions shown in panel A. Note that the p40 content (arrowhead) of each fraction strictly correlates with the level of tyrosine kinase activity observed.

below) indicated that peak A contained another 40-kDa protein in addition to $\mathrm{p} 40$. Therefore, peak $\mathrm{B}$ was used for further characterization of p40 (see below).

Kinetic properties of $\mathbf{Q 1}$ activity. The specific activity of the most highly purified yeast tyrosine kinase was over $400,000 \mathrm{U} / \mathrm{mg}$, within an order of magnitude of that reported for the human insulin receptor tyrosine kinase assayed with the same substrate (4). Given that several proteins are present in these preparations, the specific activity of a completely homogeneous preparation of the yeast Q1 kinase would presumably be higher. The $K_{m}$ for ATP of the kinase was found to be $27 \mu \mathrm{M}$ (Fig. 4A). The relationship between the reaction velocity and concentration of poly $\left(\mathrm{Glu}^{80} \mathrm{Tyr}^{20}\right)$ was complex (Fig. 4B). The phosphoacceptor substrate, being a random copolymer, probably contains numerous tyrosine phosphorylation sites, each of which could have a different affinity for the protein-tyrosine kinase. At high concentrations, the copolymer was inhibitory. Such substrate inhibition presumably is due to the presence of a fraction of the tyrosine residues in the random copolymer that are not efficient phosphoacceptor sites yet can still be bound by the enzyme. Poly $\left(\mathrm{Glu}^{80} \mathrm{Tyr}^{20}\right)$ at high concentrations is known to inhibit a variety of other enzymes $(44,45)$, including the protein-tyrosine kinase $\mathrm{p} 130^{\mathrm{v}-f p s}(4)$. Both the Q1 and Q3 activities were inhibited by $80 \mathrm{mM}$ phenylphosphate (data not shown).

In addition to $O$ phosphorylation, another covalent modification of tyrosine residues is $\mathrm{O}$ sulfation, catalyzed by 

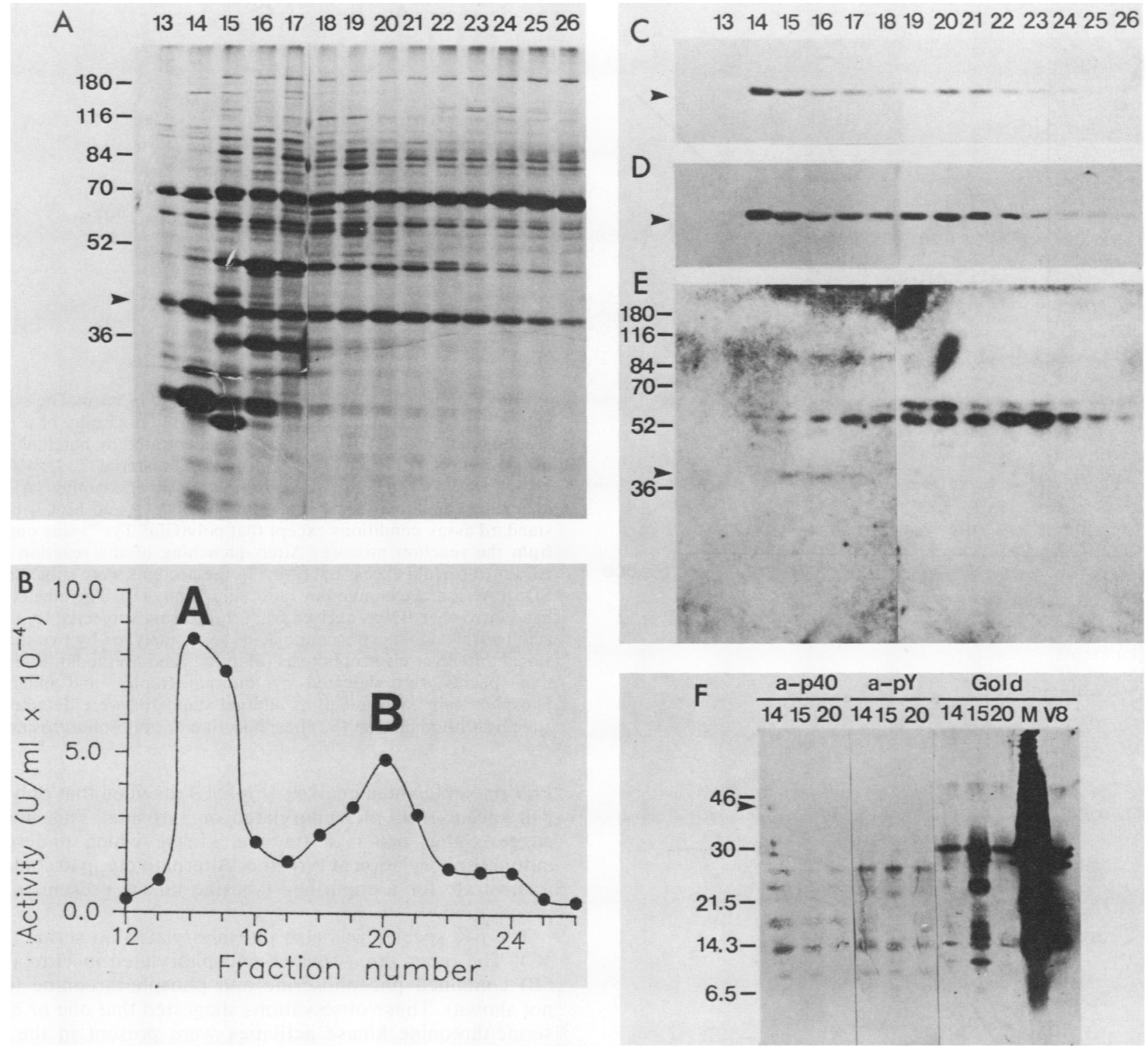

FIG. 3. Resolution of $\mathbf{p} 40$ into two fractions by Mono $\mathrm{S}$ chromatography. A large-scale preparation of p40 from commercially grown yeast cells was purified through the orange A-agarose step as described in Materials and Methods. The pooled active fractions (40,000 U; 250,000 $\mathrm{U} / \mathrm{mg}$ ) were then subjected to Mono S chromatography. p40 was separated into two chromatographically distinct species, peak A (fractions 14 and 15) and peak B (fraction 20), as judged by analysis of total proteins using SDS-PAGE and silver staining (A), by direct enzyme assay (B), and by immunoblotting with either affinity-purified anti-p40 antibodies (C) or antiphosphotyrosine antibodies (D). As determined from in situ activity staining after a renaturation procedure $(9,16)(\mathrm{E})$, peak $A$ contains a renaturable $40-\mathrm{kDa}$ kinase that is distinct from p40 and that is absent from peak B (lane 14 versus lane 15 and lane 15 versus lane 20; also compare panel $E$ with panels $C$ and $D$ ). The 40-kDa region of gel lanes from fractions 14,15 , and 20 were excised, subjected to digestion with $S$. aureus V8 protease, and analyzed by immunoblotting with affinity-purified anti-p40 antibodies (a-p40), with antiphosphotyrosine antibodies (a-pY), or by staining total protein with colloidal gold (F). Note that peak A (fraction 15) contained major peptide fragments not derived solely from p40.

tyrosyl protein sulfotransferases which utilize adenosine 3'-phosphate 5'-phosphosulfate as the sulfate donor (31). To determine whether the purified $\mathrm{p} 40$ preparations contained such a sulfotransferase activity, p40 samples were incubated with poly $\left(\mathrm{Glu}^{80} \mathrm{Tyr}^{20}\right)$ plus carrier-free $\left[{ }^{35}\right.$ S $]$ adenosine $3^{\prime}$ phosphate $5^{\prime}$-phosphosulfate under our standard assay conditions. No incorporation of the ${ }^{35} \mathrm{~S}$ label into the copolymer was detected (data not shown), indicating that the yeast activity is specific for the phosphorylation of tyrosine residues.
Purified Q1 kinase did not phosphorylate enolase, casein, or histones on tyrosine (data not shown). Thus, only two substrates phosphorylated at tyrosine by the Q1 activity have been identified: the poly $\left(\mathrm{Glu}^{80} \mathrm{Tyr}^{20}\right)$ copolymer and the $\mathrm{p} 40$ protein (see below).

Phosphorylation of $\mathbf{p 4 0}$ on tyrosine in vitro and in vivo. A preparation of $\mathrm{p} 40$, purified as described above and then concentrated by adsorption to and elution from Mono $S$ FLPC (Fig. 5A), was incubated with $\mathrm{Mn}^{2+}$ and $\left[\gamma-{ }^{32} \mathrm{P}\right] \mathrm{ATP}$. Four major phosphorylated species were observed (Fig. 5B). 

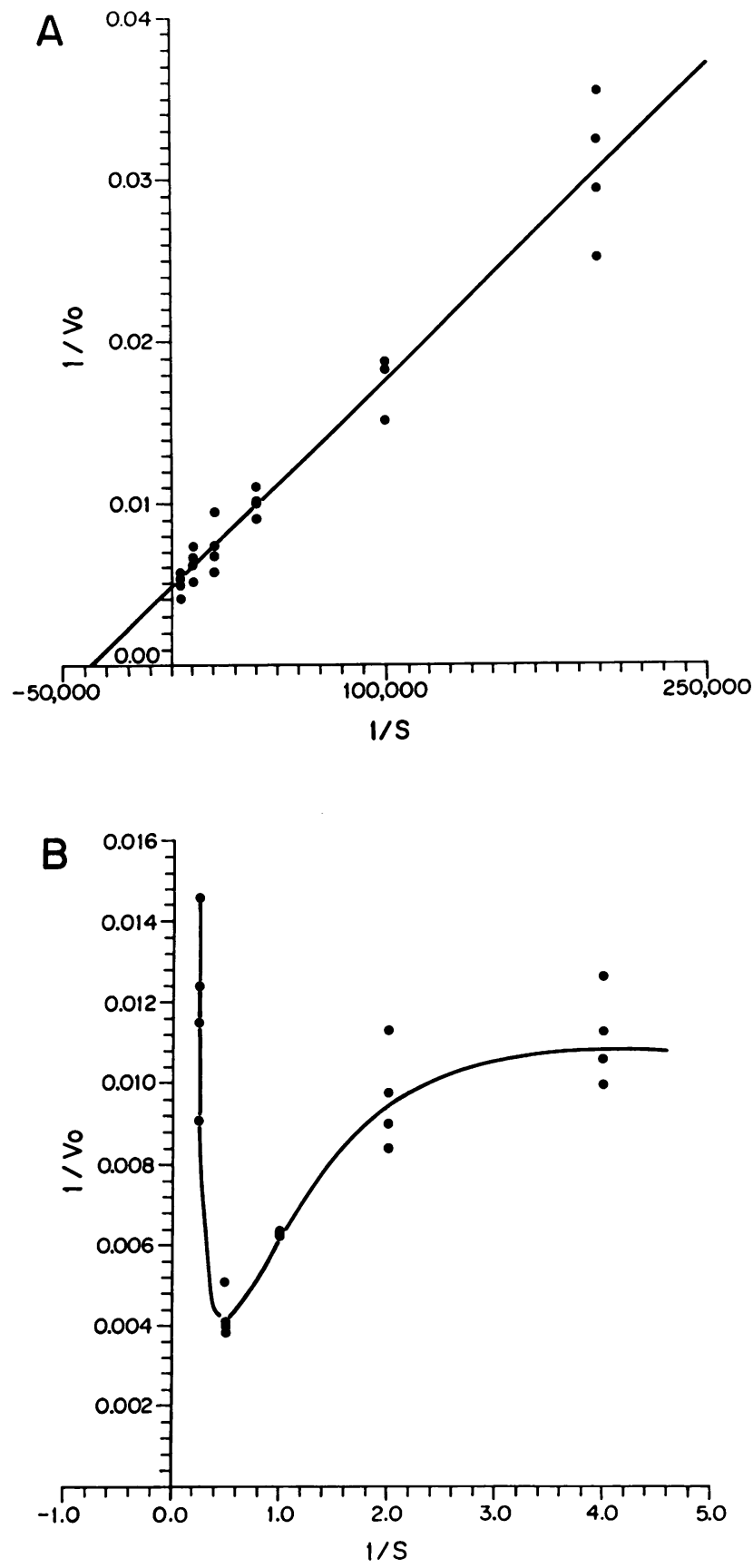

FIG. 4. Relationship between reaction velocity and substrate concentration for $\mathrm{p} 40$-associated tyrosine kinase activity. (A) Purified p40 from $\mathrm{AB} 103$ cells was added to standard reaction mixtures containing $1.67 \mathrm{mg}$ of poly $\left(\mathrm{Glu}^{80} \mathrm{Tyr}^{20}\right)$ and ATP at various concentrations from 5 to $270 \mu \mathrm{M}$ ATP. Reactions were linear with respect to time over the incubation periods used (up to $8 \mathrm{~min}$ ). (B) Assays were performed as described above in reaction mixtures containing $80 \mu \mathrm{M}$ ATP and poly $\left(\mathrm{Glu}^{80} \mathrm{Tyr}^{20}\right)$ at various concentrations from 0.25 to $4.0 \mathrm{mg} / \mathrm{ml}$. Data are plotted in the double-reciprocal (Lineweaver-Burk) format. V, Reaction velocity (femtomoles per milliliter per minute); S, substrate concentration [molar ATP in panel A; milligrams of poly $\left(\mathrm{Glu}^{80} \mathrm{Tyr}^{20}\right)$ per milliliter in panel B].

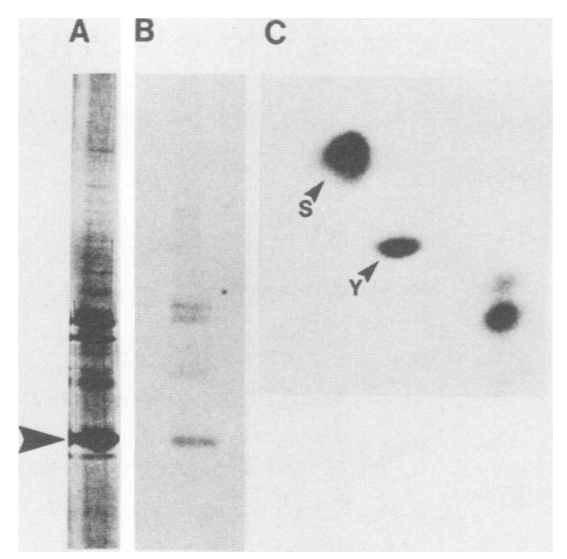

FIG. 5. Phosphorylation of $\mathrm{p} 40$ on tyrosine in vitro. The pooled active fractions from orange $\mathrm{A}$-agarose chromatography of a preparation of $\mathrm{p} 40$ from $\mathrm{AB} 103$ cells was concentrated by batch elution, using Mono $S$. A sample of the concentrated material (50 U; 400,000 $\mathrm{U} / \mathrm{mg}$ ) was analyzed by SDS-PAGE and silver staining (A). An identical sample was incubated with $\left[\gamma^{32} \mathrm{P}\right] \mathrm{ATP}$ and $\mathrm{MnCl}_{2}$ under standard assay conditions except that poly $\left(\mathrm{Glu}^{80} \mathrm{Tyr}^{20}\right)$ was omitted from the reaction mixture. After quenching of the reaction with EDTA (threefold excess over $\mathrm{Mn}^{2+}$ ), the proteins were subjected to SDS-PAGE and examined by autoradiography (B). The labeled p40 band (arrowhead) was excised from the gel and subjected to partial acid hydrolysis. Phosphoamino acids were analyzed by two-dimensional thin-layer electrophoresis (Materials and Methods). Radioactive species were detected by autoradiography, and unlabeled phosphoamino acids added as internal standards were detected by staining with ninhydrin (S, phosphoserine; $\mathrm{Y}$, phosphotyrosine).

Phosphoamino acid analysis (Fig. 5C) revealed that only the p40 species was phosphorylated on tyrosine. This finding suggests that $\mathrm{p} 40$ is a tyrosine kinase which undergoes autophosphorylation at tyrosine. Alternatively, $\mathrm{p} 40$ could be a substrate for a copurified tyrosine kinase present in the preparation.

The p40 species was also phosphorylated on serine (Fig. $5 \mathrm{C}$ ). The other three species phosphorylated in vitro (Fig. 5B) contained phosphoserine and phosphothreonine (data not shown). These observations suggested that one or more serine/threonine kinase activities were present in the p40 preparation. To examine this possibility, renaturable protein kinases in fractions from the Mono $S$ stage of a p40 purification were examined by using a modification (16) of the procedure of Celenza and Carlson (9). In this assay, protein mixtures are resolved by SDS-PAGE, electroblotted to PVDF membranes, subjected to a renaturation regimen, and then incubated with $\left[\gamma^{-32} \mathrm{P}\right]$ ATP. Renaturable kinases which can autophosphorylate, or phosphorylate comigrating substrates or components of the blocking mixture, can be detected by this procedure $(9,16)$. The results (Fig. 3) indicated that peak A contained a $40-\mathrm{kDa}$ kinase activity which was absent from peak B; phosphoamino acid analysis indicated that this kinase was phosphorylated at serine and threonine residues (data not shown). Only higher-molecularweight renaturable serine kinases were detected in peak $B$ (Fig. 3 and data not shown). Because p40 and proteintyrosine kinase activities were present in peak $B$, but the renaturable serine kinase was not, we conclude that $\mathrm{p} 40$ and the $40-\mathrm{kDa}$ serine kinase in peak $\mathrm{A}$ are distinct proteins. $\mathrm{p} 40$ and the $40-\mathrm{kDa}$ serine/threonine kinase were further distinguished by subsequent analysis with protease V8 (see below). Presumably, the serine kinases present in $\mathrm{p} 40$ prepa- 


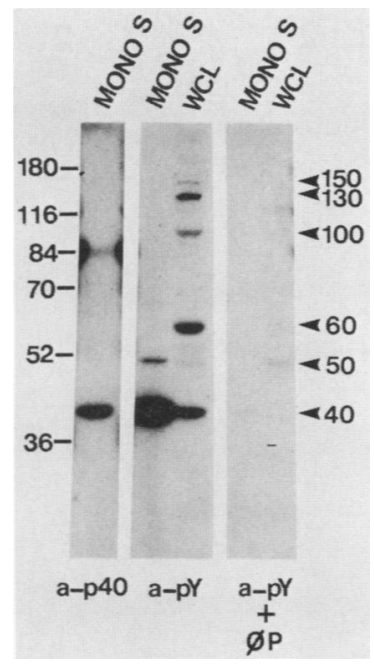

FIG. 6. Demonstration by use of antiphosphotyrosine antibodies that $\mathrm{p} 40$ and other yeast proteins contain phosphotyrosine in vivo. p40 was prepared on a large scale from commercially grown yeast cells through the Mono $S$ chromatography step. A sample of the purified protein (Mono S; 0.5 to $1 \mu \mathrm{g}$ ) and a sample of whole-cell lysate from Red Star yeast (WCL; $50 \mu \mathrm{g}$ ) were subjected to SDS-PAGE, transferred to PVDF membranes by electroblotting, and probed either with affinity-purified anti-p40 antibodies (a-p40) or with antiphosphotyrosine antibodies (a-pY) in the absence or presence of $40 \mathrm{mM}$ phenylphosphate $(\phi \mathrm{P})$. Bound antibodies were detected by using ${ }^{125} \mathrm{I}$-labeled $S$. aureus protein $\mathrm{A}$ and autoradiography.

rations are responsible for some or all of the serine phosphorylation observed when $\mathrm{p} 40$ is incubated with $\left[\gamma^{-32}\right.$ P]ATP. Labeling of p40 in peak B was not observed after the renaturation protocol, suggesting that the kinase activity of p40 was not renaturable.

To determine whether purified $\mathrm{p} 40$ contained phosphotyrosine, a sample of purified p40 was examined by immunoblotting with antiphosphotyrosine antibody. p40 reacted with antiphosphotyrosine antibody, and recognition of p40 by antiphosphotyrosine antibody was blocked by phenylphosphate (Fig. 6). In p40 preparations from AB103, no other protein was recognized by the antiphosphotyrosine antibody; in preparations from commercial yeast cells (Fig. $6)$, an additional minor species $\left(M_{\mathrm{r}} 50,000\right)$ was detected. Phosphorylation of $\mathrm{p} 40$ during the purification procedure was precluded because ATP was absent and EDTA was included in the buffers for lysis and the initial purification steps. These results suggested that $\mathrm{p} 40$ is phosphorylated at tyrosine in vivo in actively growing yeast cells. Samples of p40 were incubated with either $\mathrm{Mn}^{2+}$ or $\mathrm{Mg}^{2+}$ and ATP and then examined by immunoblotting with antiphosphotyrosine antibody. No increase in immunoreactivity was seen (not shown), in agreement with the low level of tyrosine phosphorylation detected with $\left[\gamma^{-32} \mathrm{P}\right]$ ATP (estimated at $10^{-3}$ to $10^{-2} \mathrm{~mol}$ of phosphate per mol of protein). No other species reacted with the antiphosphotyrosine antibodies after incubation with Mn- or Mg-ATP, confirming that p40 was the only protein in the preparation to be phosphorylated on tyrosine in vitro.

To determine directly whether p40 was phosphorylated at tyrosine in vivo, a polyclonal anti-p40 antibody was prepared and purified by antigen affinity chromatography. Gelpurified p40 from the peak $B$ fraction of the Mono $S$ eluate was used as immunogen and for affinity purification. When this antibody was used in immunoblotting analyses with crude yeast cell lysates, the major band recognized was at 40 $\mathrm{kDa}$ (Fig. 7A). Similarly, only one band appeared in immunoblots prepared with purified p40 (Fig. 7A). Thus, the antibody efficiently recognized only $\mathrm{p} 40$. This antibody was used to immunoprecipitate p40 from yeast cells metabolically labeled by growth in the presence of ${ }^{32} \mathrm{P}_{i}$ (Fig. 7B). The radiolabeled protein was excised from an SDS-polyacrylamide gel and subjected to phosphoamino acid analysis. Both phosphoserine and phosphotyrosine were detected, with phosphoserine being the major phosphoamino acid (Fig. 7C). These results confirm that $\mathrm{p} 40$ is phosphorylated at tyrosine in vivo.

To determine whether the $\mathrm{p} 40$ proteins present in peaks $A$ and $B$ were related and were both phosphorylated at tyrosine, fractions from a Mono $\mathrm{S}$ column were subjected to immunoblotting with anti-p40 and antiphosphotyrosine antibodies. $\mathrm{p} 40$ from both peaks was recognized by both antibodies (Fig. 3C and D). Samples from both peaks were subjected to partial proteolysis with protease V8, and the products of digestion were analyzed by immunoblotting with anti-p40 or antiphosphotyrosine antibodies. The same peptides from both peaks were recognized by anti-p40 antibody, indicating that p40 in peak $A$ is related to that in peak B (Fig. $3 F$ ). Common peptides were also observed with antiphosphotyrosine antibody (Fig. 3F). However, staining of parallel blots with colloidal gold indicated the presence in peak $A$ of additional V8 digestion products that were not recognized by either antibody (Fig. 3F), confirming the presence of another $40-\mathrm{kDa}$ protein in peak $\mathrm{A}$ (presumably the $40-\mathrm{kDa}$ serine kinase). The nature of the difference between the p40 present in peaks A and B from the Mono S column is unclear at present; the difference in elution position might result from a covalent modification such as phosphorylation, from complex formation with other cellular proteins, or from proteolysis of a few charged residues at the $\mathrm{N}$ or $\mathrm{C}$ terminus.

Isolation and sequence of the gene encoding $\mathbf{p 4 0}$. Ten unique peptides were derived by proteolysis of gel-purified p40 from peak B, using endoproteinase Lys-C. The sequences of three of these peptides permitted the design of long nondegenerate oligonucleotide probes, which were then used to screen a yeast genomic library. A clone hybridizing to all three probes was recovered, and its sequence was determined. A single 375-amino-acid open reading frame (Fig. 8) was identified which encodes a protein with a calculated $M_{\mathrm{r}}$ of 43,136 . The deduced amino acid sequence is in perfect agreement with the sequences of all 10 Lys-C peptides that had been sequenced, confirming that the cloned gene (YPKI) encodes p40. The deduced amino acid sequence of $Y P K 1$ also contains all of the conserved motifs (20) present in protein kinase catalytic domains (Fig. 8). The sequence of p40 is distinct from all sequences present in the GenBank data base and in a data base of protein kinase catalytic domains compiled by S. M. Hanks and A. M. Quinn (personal communication). Hence, the YPKI gene product is a novel protein kinase.

It has been suggested (20) that two regions (VI and VIII) within the catalytic domains of protein kinases are diagnostic of hydroxyamino acid substrate specificity. In region VI, the p40 sequence resembles the consensus sequence found in known serine/threonine kinases rather than that found in well-characterized tyrosine kinases (Fig. 9). Similarly in region VIII, the p40 sequence is more similar to the sequences in serine/threonine kinase than to those present in tyrosine kinases. However, regions VI and VIII of two tyrosine kinases from Dictyostelium discoideum have se- 
quences that do not closely match those of protein-tyrosine kinases of higher eucaryotes (47). Thus, consensus sequences derived from metazoan kinases may not be diagnostic of the hydroxyamino acid substrate specificity of protein kinases from unicellular organisms.

Detection of phosphotyrosyl proteins in yeast cell lysates. To determine whether pp40 and other phosphotyrosyl proteins could be detected in yeast cell lysates, three additional approaches were used. First, yeast cells were labeled in vivo by growth in medium containing ${ }^{32} \mathrm{P}_{\mathrm{i}}$, and cellular proteins were extracted.The total cell protein was subjected to partial acid hydrolysis and phosphoamino acid analysis. Quantitation of the recovered phosphoamino acids indicated that yeast phosphoproteins contain $89.9 \%$ phosphoserine, $10.1 \%$ phosphothreonine, and $0.04 \%$ phosphotyrosine. Second, total cell proteins from ${ }^{32} \mathrm{P}$-labeled cells were separated by one-dimensional SDS-PAGE, and individual gel slices were subjected to phosphoamino acid analysis. The major peak of phosphotyrosine was recovered in the 32- to 38-kDa range (Fig. 10). More minor but clearly detectable amounts of phosphotyrosine were recovered in the 44- to 54- and 19- to 22-kDa regions of the gel (Fig. 10). Finer slicing of the 30- to 40-kDa region of an SDS-polyacrylamide gel of ${ }^{32} \mathrm{P}$-labeled yeast proteins revealed two peaks of phosphotyrosine in this region, a minor peak at 31 to $34 \mathrm{kDa}$, which may represent the $34-\mathrm{kDa} C D C 28$ product (39), and a major peak at 39 to 40 $\mathrm{kDa}$, which probably represents $\mathrm{p} 40$. The latter band also yielded phosphotyrosine when subjected to alkali treatment before acid hydrolysis or when hydrolyzed by extensive digestion with protease instead of the conventional acid hydrolysis procedure (data not shown), confirming that the modification is authentic phosphotyrosine and not adenylyltyrosine (17).

The third approach used to detect yeast phosphotyrosyl proteins was immunoblotting with antiphosphotyrosine antibodies (Fig. 6). Bands with apparent molecular masses of $150,130,100,60$, and $40 \mathrm{kDa}$ were found to react with antiphosphotyrosine antibodies. Recognition of these species was blocked by $40 \mathrm{mM}$ phenylphosphate. The $40-\mathrm{kDa}$ band observed by immunoblotting of whole-cell lysates comigrated with the purified p40 species (Fig. 6). In some immunoblots, a 32-kDa species was detected that may represent the p34 ${ }^{c d c 28}$ protein (39). Species with apparent molecular masses of 78,170 , and $186 \mathrm{kDa}$ were also occasionally detected. The other bands detected by antiphosphotyrosine antibodies (Fig. 6) may represent other autophosphorylating kinases or substrates of yeast protein-tyrosine kinases. To determine whether the reaction of yeast proteins with antiphosphotyrosine antibodies is phosphorylation dependent, yeast lysates incubated with Mg-ATP before electrophoresis were examined by immunoblotting. Additional bands were observed after incubation with ATP; recognition of these bands was blocked by $40 \mathrm{mM}$ phenylphosphate (data not shown).

\section{DISCUSSION}

The results presented here confirm our previous findings (43) and indicate that yeast cells contain several chromatographically separable kinase species capable of phosphorylating poly $\left(\mathrm{Glu}^{80} \mathrm{Tyr}^{20}\right)$. Purification of the major soluble activity yielded preparations highly enriched in a $40-\mathrm{kDa}$ protein whose presence correlated with the level of poly $\left(\mathrm{Glu}^{80} \mathrm{Tyr}^{20}\right)$-kinase activity throughout multiple ionexchange and affinity chromatography steps. p40 could be phosphorylated at tyrosine in vitro even after extensive

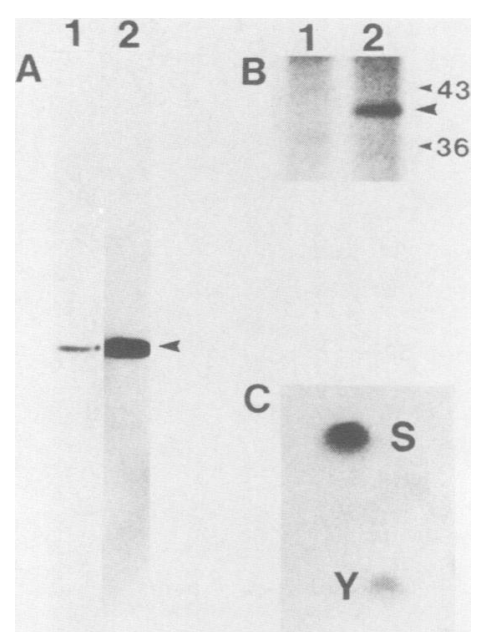

FIG. 7. Confirmation by phosphoamino acid analysis that p40 contains phosphotyrosine in vivo. (A) A sample (100 $\mu \mathrm{g})$ of wholecell lysate from strain $\mathrm{AB} 103$ (lane 1) and a sample of purified $\mathrm{p} 40$ $(0.2 \mu \mathrm{g}$; Mono $S$ fraction from $\mathrm{AB} 103$ cells; lane 2$)$ were subjected to SDS-PAGE, transferred to PVDF membranes, and examined by immunoblotting with affinity-purified anti-p40 antibodies. p40 (arrowhead) was not recognized by preimmune rabbit serum on such immunoblots. (B) Strain AB103 was metabolically labeled with ${ }^{32} \mathrm{P}_{\mathrm{i}}$ and lysed, and extracts $\left(1.2 \times 10^{9} \mathrm{cpm}\right.$ total) were subjected to immunoprecipitation, using either preimmune rabbit serum (lane 1) or affinity-purified anti-p40 antibodies (lane 2). (C) The ${ }^{32} \mathrm{P}$-labeled p40 band from the gel shown in panel B was excised, eluted, and subjected to partial acid hydrolysis. Phosphoamino acids were analyzed as described in the legend to Fig. 5.

purification, and in the most highly purified fractions, $\mathrm{p} 40$ was the only protein phosphorylated on tyrosine. The sequence of the $Y P K I$ gene which encodes p40 indicates that it is a protein kinase, because it contains all of the sequence motifs found in well-characterized protein kinases (20). In the domains previously regarded as diagnostic of hydroxyamino acid substrate specificity, regions VI and VIII (20), the sequence of p40 is more similar to the sequences in known serine/threonine kinases than to those present in most previously described tyrosine kinases.

These observations raise a number of questions about the $Y P K 1$ product, in particular its substrate specificity and the nature of the enzymes responsible for its phosphorylation at tyrosine and serine. There are several possible interpretations of our data. The first possibility is that p40 is itself a tyrosine kinase. Although the YPK1 product, p40, lacks the sequence motifs that are present in regions VI and VIII of well-characterized tyrosine kinases, it has recently been reported that two tyrosine kinases from Dictyostelium discoideum, the DPYKI and DPYK2 gene products, also lack these signature sequences (47). Thus, the tyrosine kinases of metazoa and unicellular eucaryotes might represent distinct families. If p40 is a tyrosine kinase, then the tyrosine phosphorylation of $\mathrm{p} 40$ presumably results from autophosphorylation; all known protein-tyrosine kinases that have been characterized to date are capable of autophosphorylation at tyrosine $(22,23,48)$. The serine phosphorylation of p40 in vitro could arise from phosphorylation by contaminating serine/threonine kinases present in the $\mathrm{p} 40$ preparation. The second possibility is that p40 is strictly a serine/ threonine-specific kinase. In this case, tyrosine phosphorylation of p40 would be due to an associated tyrosine kinase that copurifies with $\mathrm{p} 40$, while the serine phosphorylation of 
GAAACAAACACTCTCOGCTGCTATAGAAAGTTCCAATCTTAGGCTGAATAATGGAATACTAGTAGCTCAGTGATTATCATCATAATTGAAGCTATCATTAAA AAGCATGCAGCCATATTATGCAGGAATTATATGATCACACGTAGCTGTAGTGGCTTTCGAAAGCAGCATTCTTGCTTCCACTCAGTTCGTATGTAATGACAG TTCAGTGACOCACAAACAACACTGAAAAAAGOGACCTTCATATGCGGAAGAGGGCAGGCGTAACCTCCAAGGGAAACGACATAGATTTCGCAAGTGAGTGC CATTGTGTCGTGTTAGTAGTGTGGGCAGGCCOGTAACGTGTTTATTGATAGGAGTTAAGCOCAAGACTACAGAGTTCTTTGCTTCATCTTTCAATTTTCTTT TTATTTTOCGAAACCOCCACTCCA

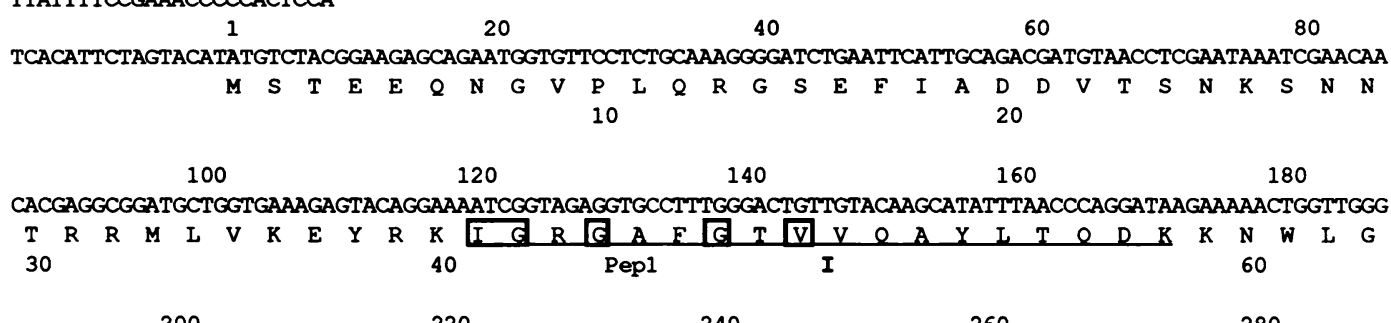

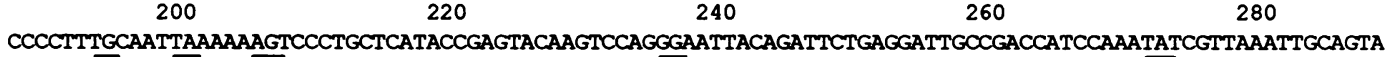

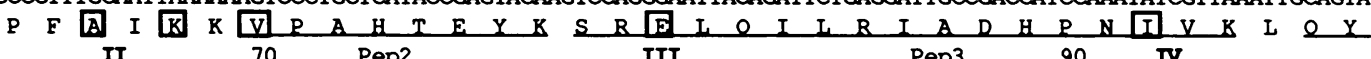
$300 \quad 320 \quad 340 \quad 360 \quad 380$

TTTCTTTACTCATTTGTCCCOGCAAGATAATAAAGTTTATCAACACCTTGCCATGGAATGCTTACCAGAAACTCTACAAATCGAGATTAATCGTTATGTGAC

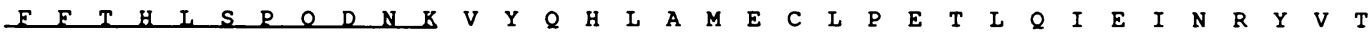
100 Pep4 $110 \quad$ V $\begin{array}{llll}400 & 420 & 440 & 460\end{array}$

AAACAAGCTAGAAATGCCATTAAAACATATCAGGCTATACACTTATCAGATTGCCCGCGGGATGCTTTATTTACACGGTCTTGGCGTTTGTCATCGTGATAT

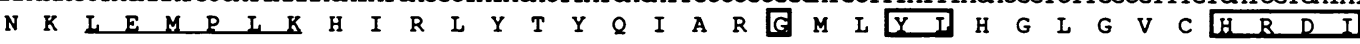
$\begin{array}{llll}\text { Pep5 } & 140 & 150 & \text { VI }\end{array}$

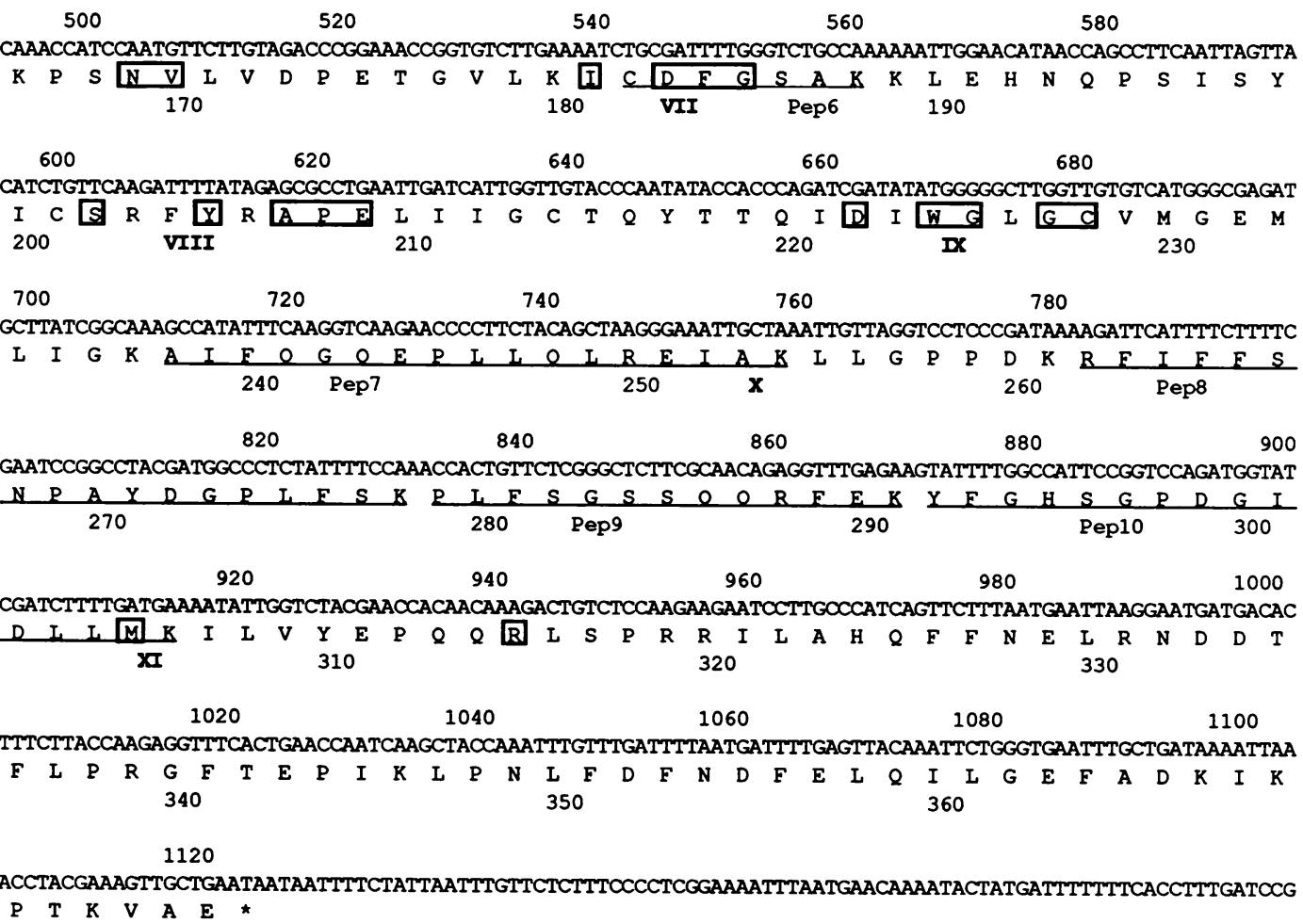

CTGTTTATATTTCACTTGGAAAAGAAAAAATTTTTTTGGAATAAAATATATTCAAATTTCCATTTGATATTATCATACACTTCTTTTATCCAGTCACTCC TTCAATTCTTCTTTATTTTTTATTTTATGTTCCTAATTTTTTTTATCTCTTTCCTATTTCCTGTTCTTTTATTAATCTGAAATATTATT

FIG. 8. Nucleotide and deduced amino acid sequences of YPK1. The sequences of the peptides (Pep1 to Pep10) derived by endoproteinase Lys-C cleavage of purified p $\mathbf{4 0}$ are underlined. Roman numerals below the amino acid sequence denote conserved kinase domain regions, and boxes denote residues that are highly conserved among protein kinases (20). The nucleotide sequence is numbered with +1 as the first base of the ATG initiator codon. The amino acid residues are numbered below.

p40 might result from either autophosphorylation, phosphorylation by other contaminating serine kinases, or both. Finally, it is possible that $\mathrm{p} 40$ is a novel bifunctional (serine/ tyrosine) kinase. To distinguish between these possibilities, the properties of bacterially expressed YPKI should be examined.

Our results demonstrate that there are a number of phosphotyrosyl proteins in yeast cells. Several other groups were 
REGION

RROTEIN KINASE

Ser/Thr kinase "consensus"
Bovine CAMP-dependent PK

YPK1 gene product

DPYK1 gene product

DPYK2 gene product

Human c-fps PK

Tyr kinase "consensus"
$\begin{array}{llllllll}H & R & D & L & K & P & E & N\end{array}$

Y R D L K P E N

H R D I K P S N

H R D L S S R N

H R D L T S $Q$

H R D L A A R N

H R D L $\begin{aligned} & A \\ & R\end{aligned} \stackrel{R}{R} N$

\begin{tabular}{l}
\hline VIII \\
G $\mathrm{T} \times \mathrm{Y}$ Y $\times$ A P E \\
G T P E Y L A P E \\
C S R F Y R A P E \\
G C I P Y M A P E \\
C N P R W R P P E \\
V P V K W T A P E \\
X P I K W T A P E
\end{tabular}

FIG. 9. Alignment of region VI and VIII sequences of YPKI with those of other protein kinases. Two regions (VI and VIII) are thought to distinguish protein-serine/threonine kinases from protein-tyrosine kinases (20). The sequences in the $Y P K l$ gene product corresponding to these two regions are aligned with those of DPYKI and DYPK2 (47), with those of a representative protein-serine/threonine kinase and a representative protein-tyrosine kinase, and with the consensus sequences deduced by Hanks et al. (20). cAMP, Cyclic AMP; PK, protein kinase.

previously unable to detect phosphotyrosine either in total yeast hydrolysates or in proteins separated by SDS-PAGE $(5,28,29)$. This discrepancy may be attributed to differences in the sensitivity of the analytical techniques used. One of the phosphotyrosyl proteins that we have detected is likely to be the product of the $C D C 28$ gene. The $S$. cerevisiae $C D C 28$ and Schizosaccharomyces pombe $c d c 2^{+}$gene products are serine/threonine-specific protein kinases that are important controlling elements of cell cycle progression (reviewed in reference 36 ). It has been reported recently that both the Schizosaccharomyces pombe $c d c 2^{+}$gene product and its mammalian homolog are phosphorylated at tyrosine in vivo $(15,19)$; the mammalian protein can be phosphorylated at tyrosine in vitro by a known tyrosine-specific kinase, pp60-src (15). The $S$. cerevisiae $C D C 28$ protein is also phosphorylated at tyrosine in vivo $(39 ; \mathrm{S}$. Reed, personal communication). Hence, one potential target of the YPKI kinase that we have purified may be the $C D C 28$ protein.

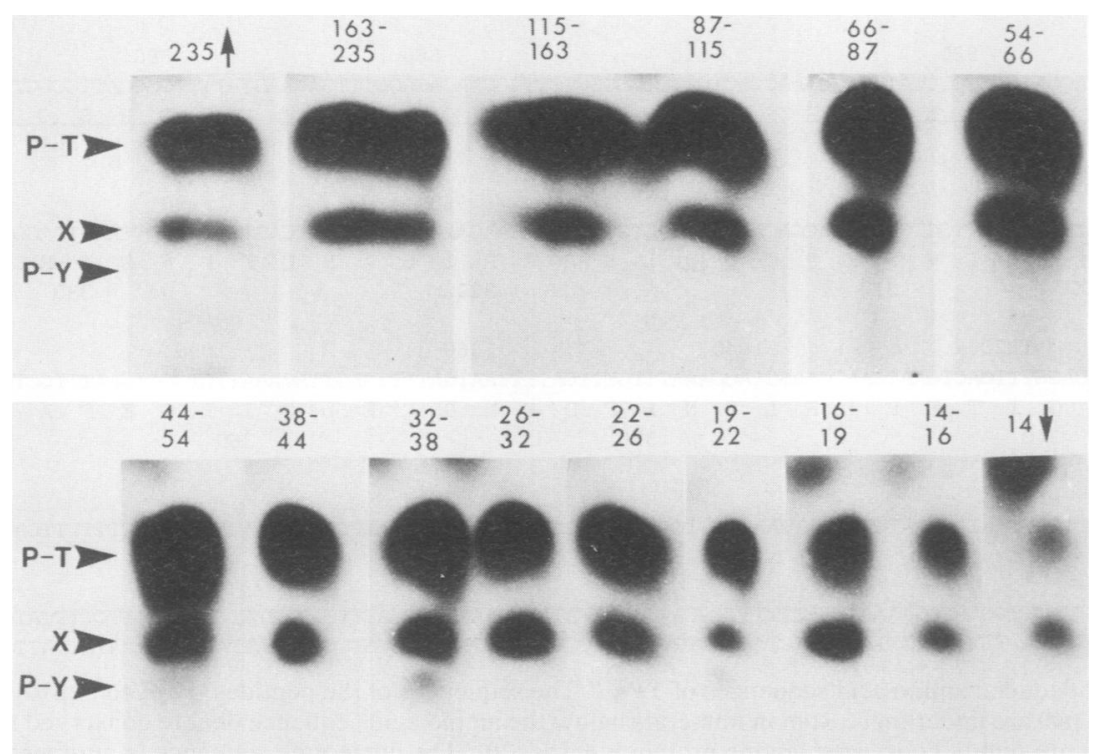

FIG. 10. Detection by phosphoamino acid analysis of multiple phosphotyrosyl proteins in yeast extracts. Strain AB103 was metabolically labeled with ${ }^{32} \mathrm{P}_{\mathrm{i}}$ and lysed in SDS sample buffer (30). The lysate was subjected to one-dimensional SDS-PAGE, 1-cm slices of the gel were excised, and proteins were eluted from the slices. The eluted proteins were precipitated and subjected to partial acid hydrolysis. Phosphoamino acids were analyzed by a modification of the standard two-dimensional thin-layer electrophoresis procedure as described in Materials and Methods. P-T, Phosphothreonine; X, an unidentified product of hydrolysis (12); P-Y, phosphotyrosine. The approximate molecular mass range (in kilodaltons) corresponding to the region of each gel slice is given above each lane; the first slice contains proteins with molecular masses greater than 235 kilodaltons, and the last slice contains proteins with molecular masses below 14 kilodaltons. 
However, preliminary experiments suggest that the $C D C 28$ protein is not phosphorylated by $\mathrm{p} 40$ in vitro (M.-Y. Lim, C. Stueland, S. Reed, and G. S. Martin, unpublished results). It has been reported that a major substrate for the $C D C 28$ kinase in immune complex kinase assays is a $40-\mathrm{kDa}$ protein (34); however, the p40 described here is not the same species because the $40-\mathrm{kDa}$ phosphoprotein coprecipitated with antiCDC28 antibody is not recognized by our affinity-purified anti-p40 antibody (S. Reed, personal communication).

The genetic tools that are available for the study of gene function in yeast cells should allow an analysis of the function of the YPKI kinase that we have described here.

\section{ACKNOWLEDGMENTS}

D.D. and G.L.S. contributed equally to this work, and the sequence of names of these two authors is therefore arbitrary.

We thank Janet Carminati, Phuong Ta, and Sujatha Nagulapalli for technical assistance; Bob Lesch for assistance in the large-scale growth of yeast cells; Mark Kamps for the gift of antiphosphotyrosine antibodies; David Drubin for advice on the preparation of anti-p40 antiserum; Trevor Williams for advice on cloning procedures; and Jim Ferrell for comments on the manuscript.

This work was supported by grant MV283 from the American Cancer Society and Public Health Service grant GM44173 from the National Institutes of Health (both to G.S.M. and J.T.). G.L.S., D.D., and M.Y.L. were supported by Public Health Service training grant CA09041 from the National Institutes of Health; G.L.S. was also supported by National Research Service award GM10384 from the National Institutes of Health and by a fellowship from the Leukemia Society of America.

\section{LITERATURE CITED}

1. Ammerer, G., C. P. Hunter, J. H. Rothman, G. C. Saari, L. A. Valls, and T. H. Stevens. 1986. PEP4 gene of Saccharomyces cerevisiae encodes proteinase A, a vacuolar enzyme required for processing of vacuolar precursors. Mol. Cell. Biol. 6:24902499.

2. Botstein, D., and G. R. Fink. 1988. Yeast: an experimental organism for modern biology. Science 240:1439-1443.

3. Bradford, M. M. 1976. A rapid and sensitive method for the quantitation of microgram quantities of protein utilizing the principle of protein-dye binding. Anal. Biochem. 72:248-254.

4. Braun, S., W. E. Raymond, and E. F. Racker. 1984. Synthetic tyrosine polymers as substrates and inhibitors of tyrosinespecific protein kinases. J. Biol. Chem. 259:2051-2054.

5. Brugge, J. S., G. Jarosik, J. Anderson, A. Queral-Lustig, M. Fedor-Chaiken, and J. R. Broach. 1987. Expression of Rous sarcoma virus transforming pp60 ${ }^{\mathrm{v}-s r c}$ in Saccharomyces cerevisiae. Mol. Cell. Biol. 7:2180-2187.

6. Burnette, W. N. 1981. "Western blotting": electrophoretic transfer of proteins from sodium dodecyl sulfate-polyacrylamide gels to unmodified nitrocellulose and radiographic detection with antibody and radioiodinated protein A. Anal. Biochem. 112:195-203.

7. Carlson, M., and D. Botstein. 1982. Two differentially regulated mRNAs with different 5 '-ends encode secreted and intracellular forms of yeast invertase. Cell 28:145-154.

8. Castellanos, R. M. P., and M. J. Mazon. 1985. Identification of phosphotyrosine in yeast proteins and of a protein tyrosine kinase associated with the plasma membrane. J. Biol. Chem. 260:8240-8242.

9. Celenza, J. L., and M. Carlson. 1986. A yeast gene that is essential for release from glucose repression encodes a protein kinase. Science 233:1175-1180.

10. Cleveland, D. W., S. G. Risher, M. W. Kirschner, and U. K. Laemmli. 1977. Peptide mapping by limited proteolysis in sodium dodecyl sulfate and analysis by gel electrophoresis. J. Biol. Chem. 252:1102-1106.

11. Cooper, J., and T. Hunter. 1983. Regulation of cell growth and transformation by tyrosine-specific protein kinases: the search for important cellular substrate proteins. Curr. Top. Microbiol.
Immunol. 107:125-161.

12. Cooper, J. A., B. M. Sefton, and T. Hunter. 1983. Detection and quantification of phosphotyrosine in protein. Methods Enzymol. 99:387-402.

13. Davis, T. N., and J. Thorner. 1987. Isolation of the yeast calmodulin gene using synthetic oligonucleotide probes. Methods Enzymol. 139:248-262.

14. DeClue, J. E., and G. S. Martin. 1987. Phosphorylation of talin at tyrosine in Rous sarcoma virus-transformed cells. Mol. Cell. Biol. 7:371-378.

15. Draetta, G., H. Piwnica-Worms, D. Morrison, B. Druker, T. Roberts, and D. Beach. 1988. Human cdc2 protein kinase is a major cell-cycle regulated tyrosine kinase substrate. Nature (London) 336:738-744.

16. Ferrell, J. E., and G. S. Martin. 1989. Thrombin stimulates the activities of multiple previously unidentified protein kinases in platelets. J. Biol. Chem. 254:7961-7977.

17. Foster, R., J. Thorner, and G. S. Martin. 1989. Nucleotidylation, not phosphorylation, is the major source of the phosphotyrosine detected in enteric bacteria. J. Bacteriol. 171:272-279.

18. Fuller, R. S., A. Brake, and J. Thorner. 1989. Yeast prohormone processing enzyme (KEX2 gene product) is a $\mathrm{Ca}^{2+}$-dependent serine protease. Proc. Natl. Acad. Sci. USA 86:1434-1438.

19. Gould, K. L., and P. Nurse. 1989. Tyrosine phosphorylation of the fission yeast $c d c 2^{+}$protein kinase regulates entry into mitosis. Nature (London) 342:39-45.

20. Hanks, S. K., A. M. Quinn, and T. Hunter. 1988. The proteinkinase family: conserved features and deduced phylogeny of the catalytic domains. Science 241:42-52.

21. Hunkapiller, M. W., E. Lujan, F. Ostrander, and L. E. Hood. 1983. Isolation of microgram quantities of proteins from polyacrylamide gels for amino acid sequence analysis. Methods Enzymol. 91:227-236.

22. Hunter, T. 1989. Oncogene products in the cytoplasm: the protein kinases, p. 147-173. In R. A. Weinberg (ed.), Oncogenes and the molecular origins of cancer. Cold Spring Harbor Laboratory, Cold Spring Harbor, N.Y.

23. Hunter, T., and J. A. Cooper. 1985. Protein-tyrosine kinases. Annu. Rev. Biochem. 54:897-930.

24. Jones, E. W. 1977. Proteinase mutants of Saccharomyces cerevisiae. Genetics 85:23-33.

25. Jones, W. E. 1984. The synthesis and function of proteases in Saccharomyces: genetic approaches. Annu. Rev. Genet. 18: 233-270.

26. Julius, D., R. Schekman, and J. Thorner. 1984. Glycosylation and processing of prepro- $\alpha$-factor through the yeast secretory pathway. Cell 36:309-318.

27. Kamps, M. P., and B. M. Sefton. 1988. Identification of multiple novel polypeptide substrates of the v-src, v-yes, v-fps, v-ros, and $v$-erb-B oncogenic tyrosine protein kinases utilizing antisera against phosphotyrosine. Oncogene 2:305-315.

28. Kanik-Ennulat, C., and N. Neff. 1990. Vanadate-resistant mutants of Saccharomyces cerevisiae show alterations in protein phosphorylation and growth control. Mol. Cell. Biol. 10:898909.

29. Kornbluth, S., R. Jove, and H. Hanafusa. 1987. Characterization of avian and viral ${\mathrm{pp} 60^{\mathrm{src}}}^{\mathrm{si}}$ proteins expressed in yeast. Proc. Natl. Acad. Sci. USA 84:4455-4459.

30. Laemmli, U. K. 1970. Cleavage of structural proteins during the assembly of the head of bacteriophage T4. Nature (London) 277:680-685.

31. Lee, R. W. H., and W. B. Huttner. 1983. Tyrosine-O-sulfated proteins of $\mathrm{PC} 12$ pheochromocytoma cells and their sulfation by a tyrosylprotein sulfotransferase. J. Biol. Chem. 258:1132611334.

32. Marquardt, H., M. N. Lioubin, and T. Ikeda. 1987. Complete amino acid sequence of human transforming growth factor type B2. J. Biol. Chem. 262:1217-12131.

33. Mechler, B., H. Muller, and D. H. Wolf. 1987. Muturation of vacuolar (lysosomal) enzymes in yeast: proteinase YscA and proteinase $\mathrm{YscB}$ are catalysts of the processing and activation event of carboxypeptidase YscY. EMBO J. 6:2157-2163.

34. Mendenhall, M. D., C. A. Jones, and S. I. Reed. 1987. Dual 
regulation of the yeast CDC28-p40 protein kinase complex: cell cycle, pheromone and nutrient limitation effects. Cell 50:927935.

35. Morrissey, J. H. 1981. Silver stain for proteins in polyacrylamide gels: a modified procedure with enhanced uniform sensitivity. Anal. Biochem. 117:307-310.

36. Nurse, P. 1990. Universal control mechanism regulating onset of $M$ phase. Nature (London) 344:503-508.

37. Pringle, J. R., and L. H. Hartwell. 1981. The Saccharomyces cerevisiae cell cycle, p. 97-142. In J. N. Strathern, E. W. Jones, and J. R. Broach (ed.), Molecular biology of the yeast Saccharomyces: life cycle and inheritance. Cold Spring Harbor Laboratory, Cold Spring Harbor, N.Y.

38. Radke, K., and G. S. Martin. 1979. Transformation by Rous sarcoma virus: effects of $s r c$ gene expression on the synthesis and phosphorylation of cellular polypeptides. Proc. Natl. Acad. Sci. USA 76:5212-5216.

39. Reed, S. I., J. A. Hadwiger, and A. T. Lorincz. 1985. Protein kinase activity associated with the product of the yeast cell division cycle gene CDC28. Proc. Natl. Acad. Aci. USA 82: 4055-4059.

40. Reneke, J., K. Blumer, W. F. Courchesne, and J. Thorner. 1988. the carboxyl terminal domain of the yeast $\alpha$-factor receptor is a regulatory domain. Cell 55:221-234.
41. Ross, A. H., D. Baltimore, and H. N. Eisen. 1981. Phosphotyrosine-containing proteins isolated by affinity chromatography with antibodies to a synthetic hapten. Nature (London) 294:654 656.

42. Sanger, F., S. Nicklen, and A. R. Coulson. 1977. DNA sequencing with chain-terminating inhibitors. Proc. Natl. Acad. Sci. USA 74:5463-5467.

43. Schieven, G., J. Thorner, and G. S. Martin. 1986. Proteintyrosine kinase activity in Saccharomyces cerevisiae. Science 231:390-393.

44. Sela, M. 1962. Inhibition of ribonuclease by copolymers of glutamic acid and aromatic amino acids. J. Biol. Chem. 237:418421.

45. Sela, M., and L. A. Steiner. 1963. Inhibition of lysozyme by some copolymers of amino acids. Biochemistry 2:416-421.

46. Sherman, F., G. R. Fink, and C. W. Laurence. 1979. Methods in yeast genetics: a laboratory manual. Cold Spring Harbor Laboratory, Cold Spring Harbor, N.Y.

47. Tan, J. L., and J. A. Spudich. 1990. Developmentally regulated protein-tyrosine kinase genes in Dictyostelium discoideum. Mol. Cell. Biol. 10:3578-3583.

48. Yarden, Y., and A. Ullrich. 1988. Growth factor receptor tyrosine kinases. Annu. Rev. Biochem. 57:443-478. 